УДК 629.113

UDC 629.113

Войчишин Ю.I., Круць Т.І., Зінько Р.В., Горбай О.3.

Національний університет «Львівська політехніка»

\title{
ДОСЛІДЖЕННЯ МІКРОКЛІМАТУ САЛОНУ МІСЬКОГО АВТОБУСА
}

\begin{abstract}
У роботі проведено аналіз існуючих наукових досліджень вітчизняних та зарубіжних вчених у галузі дослідження мікроклімату транспортних засобів (автобусів, електробусів, легкових автомобілів та тракторів). Проаналізовано стан досліджень та наведено які питання цього напрямку наукових досліджень потрібно дослідити. Показано проблеми та їх вирішення за допомогою запропонованих методик наведених у наукових роботах вчених 3 різних країн світу. Розглянуто структуру та основні функції, які виконують системи забезпечення мікроклімату в салонах автобусів, автомобілів та тракторів сільськогосподарського призначення, а також наведено проблематику, мету та суть подальших можливих досліджень.

За допомогою комп'ютерного моделювання створено симуляційну $3 \mathrm{D}$ - модель повітряних потоків в салоні великогабаритного міського низькопідлогового автобуса. По-перше, за допомогою такої моделі можна як візуально побачити, так і дослідити параметри повітряних потоків, утворення зон холодного та гарячого повітря, визначити зони турбулентності у салоні того чи іншого транспортного засобу. По-друге, дослідження за допомогою програмного забезпечення (САПР) дозволяє дещо знизити вартість досліджень та дозволяє менше часу затрачати на практичні дослідження Проведено порівняння отриманих результатів із науковими дослідженнями інших вчених, які досліджували подібну тематику.

Результати досліджень даної роботи можуть в подальшому слугувати базою для більш широкого дослідження, аналізу проблем та подання рекомендацій при проектуванні чи при усуненні проблем систем забезпечення мікроклімату салону транспортного засобу.

Ключові слова: мікроклімат пасажирського салону, система опалення, вентиляція салону, кондиціонування салону, потоки повітря, зона турбулентності, турбулентні потоки, джерело обігріву, температурні поля.
\end{abstract}

\section{ВСТУП}

Зростання обсягів пасажирських перевезень не повинно супроводжуватися погіршенням якості транспортного обслуговування i, це, в першу чергу відноситься до створення таких комфортних умов, які забезпечили б хороше самопочуття пасажирів.

Одним 3 факторів, що визначають самопочуття пасажирів, є мікроклімат в салоні ТЗ. До параметрів, які характеризують його відносяться температура, вологість, рухливість повітря та наявність в ньому шкідливих речовин. Використовувані сьогодні методики розрахунків $\mathrm{i}$ проектування систем опалення і вентиляції базуються на інтегральних методах, які дозволяють визначати лише усереднені показники параметрів потоку. Головна роль при проектуванні таких систем відводиться експериментальним дослідженням, дорожнім і кліматичним випробуванням, що $\epsilon$ затратним. Тому важливим $\epsilon$ визначення основних параметрів мікроклімату на стадії проектування чи вдосконалення зразку і вони повинні базуватися на нових технологіях проектування таких систем 3 використанням САПР, а натурні випробовування мали б завершальний характер і були б менше затратними.

\section{АНАЛІЗ ЛІТЕРАТУРНИХ ДАНИХ ТА ПОСТАНОВКА ПРОБЛЕМИ}

Мікроклімат в салоні автобуса (опалення, вентиляція, кондиціонування) належать до трьох пріоритетних чинників формування комфортності пасажирських перевезень [1]. В силу суттєвих відмінностей клімату різних країн нормативні вимоги щодо вимог і оцінки відповідності систем опалення, вентиляції і кондиціонування не входять в міжнародну базу Правил СЕК ООН, що сконцентровані у сфері безпеки і екології руху, та відносяться до національних баз стандартів (напр. у ФРН - DIN 1946-3, DIN 33403, DIN ENISO 7730 1995), ГОСТ Р 50993-96, [2].

Розбивка окремих кліматичних районів по групах, в яких рекомендується використання автобусів різних модифікацій існує уже давно [3]. Згідно цієї розбивки для холодної зони рекомендується дві модифікації автобусів: полярна для роботи в дуже холодних районах і північна для роботи в холодному районі, нормальна для роботи в групі районів помірної зони і тепловологої зони та південна для роботи в районах жаркої зони.

На сьогоднішній день, практично всі Т3 комплектуються кліматичними установками. Створення сприятливого температурного режиму в салоні при перевозці пасажирів з найменшими енергозатратами є необхідною умовою для великогабаритних ТЗ. Якщо такі дослідження раніше проводилися лише для автобусів, то в публікації [4] це поширено і для електробусів. Було проведено експеримент для отримання температурного поля в салоні електробуса. За допомогою 27 
температурних індикаторів в салоні електробуса вимірювалась температура у 4-х умовних зонах (кабіна водія, зона ніг, поясу та голови). При експерименті всі опалювачі та калорифери працювали на максимальній потужності, електробус під час руху на маршруті (M2, Москва) здійснював рух із зупинками без висадки та посадки пасажирів.

Для організації природної вентиляції салону автобуса використовуються вентиляційні отвори, розміщені на бокових поверхнях [5]. Під час руху в салоні утворюється розрідження, що утворює потік повітря через відкриті вентиляційні отвори і негерметичності кузова і провокує запиленість салону. Особливо некомфортна зона поверхні автобуса з точки погляду забруднення повітря в салоні знаходиться в середній його частині, починаючи в одній третій від лобової частини і закінчуючи перед заднім звисом. Основна кількість негерметичностей є сконцетровано в дверях автобуса, так як практично важко забезпечити високу степінь їх герметичності і хорошу роботоздатність.

Інтегровану систему вентиляції і кондиціонування кабіни водія автобуса 3 теплообмінниками на кінці вихревої труби і кращими експлуатаційними характеристиками системи в цілому запропоновано для автобуса марки «Волжанин» [6]. Для неї проведено удосконалення вихревої труби 3 викривленою камерою енергетичного розділення, що відповідають гнучким схемам інтегрованих схем, що забезпечують комфортні умови роботи водія автомобіля. Запропоновано параметри «теплонапруження кабіни» $\mathrm{i}$ «коефіцієнт комфортності» для оцінки ефективності системи кондиціонування і вентиляції автомобіля з якісною і кількісною оцінкою.

Систему кондиціонування автобуса слід вибирати, враховуючи ряд параметрів, включаючи місткість пасажирів, місцеві кліматичні умови та витрату палива. Можна встановити, чи вибрана система кондиціонування забезпечує бажані показники за допомогою тестування. Дослідження у роботі [7] вивчає, як експериментально перевірити, чи відповідає система кондиціонування автобусів вимогам дизайну та комфорту. Експериментальне дослідження було проведено на прототипі автобуса і було випробувано під час руху на трасі Адана-Джейхан у Туреччині. Вимірювали внутрішню та зовнішню температури, температуру на вході та на виході випарника та значення відносної вологості. Значення теплового відчуття розраховували за допомогою емпіричних кореляцій, поданих ASHRAE. Крім того, миттєве навантаження на рівень охолодження отримано за експериментальними даними, $\mathrm{i}$ результати порівнюються з розрахованим рівнем охолодженням за допомогою методу променевого часового ряду, передбаченого ASHRAE. Що стосується отриманих результатів, обрана система кондиціонування повітря відповідала вимогам конструкції та комфорту.

Термодинамічний аналіз кондиціонера для автобуса міських перевезень місткістю 56 осіб проведено у дослідженні [8]. Були отримані та детально оцінені корисні та оборотні роботи компресора, коефіцієнт продуктивності, енергетична ефективність та виснаження руйнування системи кондиціонування салону.

Числове моделювання швидкості теплових потоків в кабіні транспортного засобу розглянуто у [9], де описано розрахунок системи кондиціонування кабіни і запропонована методика оптимізації управління під час випадкових зовнішніх впливів середовища.

Структура трьохмірного турбулентного потоку в багатоканальному корпусі системи опалення легкового автомобіля в залежності від режиму роботи нагнітавача досліджена у роботі [10], що дозволило отримати локальні і інтегральні характеристики стаціонарних внутрішніх потоків в трактах системи опалення залежно від геометрії і граничних умов.

Математична модель тепловологого розрахунку системи «Кондиціонер-кабіна» враховує вологість і рух теплових потоків, які забезпечують комфортний мікроклімат автомобіля [11]. На основі розробленої автором математичної моделі були побудовані алгоритми і програма тепло вологого розрахунку системи «Кондиціонер-кабіна» - автомобіля на мові FORTRAN. B ході експерименту для вимірювання температури в салоні автомобіля ВАЗ - 21083 використовували цифровий та інфрачервоний цифровий термометр.

Результати вивчення вимог до мікроклімату салону автомобіля, його вплив на безпеку руху, розроблені алгоритми вибору конструктивних елементів систем забезпечення комфортних умов подані у роботі [12], у якій проведена оцінка ефективності процесу обігріву вікон, а також визначена ефективність вентиляції і опалення салону легкового автомобіля. Створений алгоритм дозволяє порівняти конструктивні рішення і визначити вплив параметрів мікроклімату на ефективність всієї роботи системи в цілому. Користуючись алгоритмом в процесі підбору швидкостей оборотів, потужностей i продуктивності вентилятора, геометричних розмірів і тепловіддачі радіатора, продуктивності насоса, була вибрана раціональна конструкція.

Аналіз вимог державних і міжнародних нормативних документів по мікроклімату салону 
(кабіни) КТЗ проведено у роботі [13], і встановлені основні розбіжності вимог в державних та міжнародних нормативних документах, що відносяться до мікроклімату транспортних засобів, а аналіз існуючих вимог державних та міжнародних нормативних документів, що пред'являються до мікроклімату кабін мобільної техніки для сільськогосподарського виробництва та методів випробування його параметрів подано у [14].

Салон автомобіля являє собою складну конструктивну систему з різноманітністю складових іiі елементів огороджуючих конструкцій та енергетичного обладнання, в яких протікають різні фізичні процеси поглинання, перетворення та переносу теплоти. На ці розподілення впливають зовнішні фактори, такі як температура зовнішнього повітря, його вологість, а також швидкість руху повітря. Таким чином у [15] запропонована разроблена система кондиціонування повітря (СКП), яка призначена для автоматичної підтримки мікроклімату, забезпечуючи сумісну роботу систем опалення, вентиляції та кондиціонування за рахунок электронного блока управления.

Коли компресор працює постійно, що надзвичайно енергозатратно, і впливає на внутрішнє і зовнішне теплове навантаження системи мікроклімату [16]. Крім того, теплове навантаження постійно змінюється, потрібно задіювати контролер для адаптації системи до особливостей теплового навантаження. Пропонується оптимальний метод управління, щоб забезпечити збалансовану потужність охолодження i, як результат, створити максимально комфортну обстановку всередині салону з мінімальними витратами енергії.

Енергія від вихлопу двигуна внутрішнього згоряння може використовуватись для живлення поглинальної холодильної системи для кондиціонування звичайного пасажирського автомобіля. Дослідження [17] було зроблено для визначення енергії, яка доступна від відпрацьованих газів автомобіля. У цій роботі представлена теоретична оцінка системи абсорбційного охолодження на основі LiBr-Water, що являє собою сполуку літіюброміду із водою. Ця хімічна сполука використовується із-за своєї високої гігроскопічності як осушувач у кондиціонерах. Проведено математичне моделювання системи за допомогою програмного забезпечення EES для з'ясування необхідної енергії, взятої з відпрацьованих газів транспортного засобу.

При вивченні динаміки температури і вологості повітря в салоні автомобіля враховують концепцію ентальпії при аналізі теплообміну [18]. Зі зміною тепла, що розкладається на чутливе тепло та приховане тепло, ми маємо змогу вивести динаміку температури та вологості після врахування різниці чутливого коефіцієнта тепла та апаратного коефіцієнта тепла. Ці два компоненти для сенсорного i прихованого тепла використовуються в поєднанні 3 двома контрольними стратегіями швидкості подачі повітря, для імітації процесів в автомобільному салоні при постійній ентальпії і постійній температури.

Для вивчення більш реальних показників системи та фізичних процесів, що відбуваються в автомобільній установці 3 кондиціонером у спеціальних дослідних лабораторіях $\epsilon$ в наявності спеціальні дослідні стенди. Стенд [19] розроблений спеціально для того, щоб висвітлити процеси, що відбуваються в кожному компоненті установки, і як можна змінити функціональні параметри установки, відповідно до вимог користувача.

Національна лабораторія відновлюваної енергії (NREL, Washington) розробила перехідну систему кондиціонування повітря та іiі модель 3 використанням програмного забезпечення для дослідження фізики перехідних процесів системи кондиціонування, іiї продуктивності, включаючи двофазні ефекти потоку в випарник та конденсатор, масові ефекти системи, передачу тепла на конденсатор/випарник, температурнозалежні властивості системи та інтеграцію зі спрощеною тепловою моделлю кабіни [20]. Дослідження зосереджені на системах A / C R-134a, але майбутні зусилля модифікують модель для дослідження тимчасових характеристик альтернативних систем холодоагенту, таких як системи вуглекислого газу. NREL інтегрує свою перехідну модель кондиціонування в програмне забезпечення для системного аналізу систем автомобілів ADVISOR, 3 метою одночасної оптимізації конструкцій системи кондиціонування в рамках загальної оптимізації дизайну автомобіля.

3 проведеного огляду можна зробити наступні висновки:

1. Дослідження проводяться в напрямках вдосконалення систем вентиляції, обігріву i конденсування з урахуванням вимог державних та міжнародних нормативних документів.

2. В системах вентиляції досліджуються складові системи (вентилятори, елементи повітропроводів, розміщення вхідних отворів) і їх вплив на ефективність системи вентиляції в цілому.

3. В системах обігріву досліджуються параметри і характеристики теплових потоків при різних 
режимах роботи агрегатів цієї систем.

4. В системах кондиціонування досліджуються перехідні процеси їх роботи, забезпечення стабільності основних параметрів і характеристик, що формують мікроклімат пасажирського салону.

5. Для досліджень застосовуються методи системного аналізу, натурного експерименту і математичного моделювання 3 рішенням отриманих диференціальних рівнянь методом чисельного інтегрування, техніко-економічного аналізу, методами теплового балансу.

\section{ЦІЛЬ ТА ЗАДАЧІ ДОСЛІДЖЕННЯ}

Система вентиляції кузова і кабіни служить для надходження свіжого повітря в салон, його вентиляції, створення в кузові надмірного тиску, який перешкоджає проникненню в кузов пилу і холодного повітря через нещільність вікон і дверей.

Система опалювання кузова і кабіни служить для обігріву кузова і вітрового скла в холодний період року для компенсації теплових втрат захисними конструкціями і підтримки в кузові і кабіні нормованої температури повітря.

Система кондиціонування служить для створення мікроклімату і автоматичної підтримки (регулювання) в кузові і кабіні всіх або окремих параметрів (температури, вологості, чистоти, швидкості руху повітря) на певному рівні з метою забезпечення оптимальних метеорологічних умов, найбільш сприятливих для самопочуття водія і пасажирів і здійснюється комплексом технічних засобів.

Дослідження в напрямку забезпечення комфортних кліматичних умов пасажирів і водія транспорних засобів можна проводити в двох напрямках: вдосконалення системи вентиляції i вдосконалення системи обігріву та кондиціювання.

Метою дослідження систем вентиляції $є$ підвищення техніко-експлуатаційних показників системи вентиляції ТЗ шляхом вибору ефективного агрегатів, зокрема вентилятора, з урахуванням впливу набігаючого потоку, застосування часткової рециркуляції.

Об'єктом дослідження є процеси вентиляції салону ТЗ.

Предметом досліджень є система вентиляції салону ТЗ.

Для реалізації поставленої мети необхідно вирішити наступні задачі дослідження:

•створити математичну модель, що описує процес взаємодії повітряного потоку на лопать вентилятора;

•теоретично дослідити вплив набігаючого потоку, на роботу вентилятора, а також системи вентиляції загалом;

-дослідити вплив повітряних потоків в салоні ТЗ на мікроклімат;

•експериментально дослідити характеристики системи вентиляції;

-розробити і випробувати дослідну систему вентиляції із застосуванням часткової рециркуляції повітря, економічного вентилятора, обраного з урахуванням впливу набігаючого потоку.

Метою дослідження систем опалювання $є$ підвищення техніко-експлуатаційних показників системи обігріву ТЗ шляхом покращення внутрішньої аеродинаміки салону

Об'єктом дослідження є процеси опалювання салону ТЗ.

Предметом досліджень є система опалювання салону ТЗ

Для реалізації поставленої мети необхідно вирішити наступні задачі дослідження:

•отримати теоретичне рішення для моделювання нестаціонарного режиму обігріву салону, в тому числі для системи опалювання з частковою рециркуляцією повітря;

•доповнити і уточнити математичну модель;

•експериментально дослідити характеристики системи обігріву;

•визначити раціональні параметри нагрівника салону і розробити рекомендації з удосконалення системи опалювання на підставі техніко-економічного аналізу.

\section{РЕЗУЛЬТАТИ ДОСЛІДЖЕНЬ}

В процесі досліджень мікроклімату салону великогабаритного ТЗ було створено за допомогою комп'ютерного моделювання симуляційну 3D - модель салону пасажирського трьохдверного (формула дверей $1+2+2$ ) міського автобуса великого класу. За допомогою такої моделі можна як візуально побачити, так і дослідити параметри повітряних потоків у салоні автобуса. На рис. 1 та рис. $2 є$ показані скрин-шоти процесу руху повітряних потоків в салоні.

В напрямку вдосконалення системи вентиляції досліджувалися турбулентні об'ємні потоки вентильованого повітря з застосовуванням рівняння Нав'є-Стокса усередненому по Рейнольдсу [21, 22]. Досліджувалися три різних швидкості руху (25 км/год, 45 км/год, 65 км/год) і для варіантів вентиляційних отворів: вікна закриті, відкриті тільки люки вентиляціії на даху [23]. Повітря 
потрапляє в салон через люки, перміщується вздовж салону до задньої стінки салону, поступово зупиняючись, розтікається і рухається уздовж підлоги та назад. Потік частково виходить назовні через вентиляційний отвір на задній стінці салону. Повітря в салоні на різних швидкостях руху автобуса має подібну структуру, яка визначається відкриттям/закриттям вікон. Важливим $\epsilon$ враховувати вплив кватирок на рух повітряних потоків (рис. 1). Досліджується експлуатація автобуса літом. Температура довкілля $+34^{\circ} \mathrm{C}$. Температура в салоні автобуса $+43^{\circ} \mathrm{C}$.

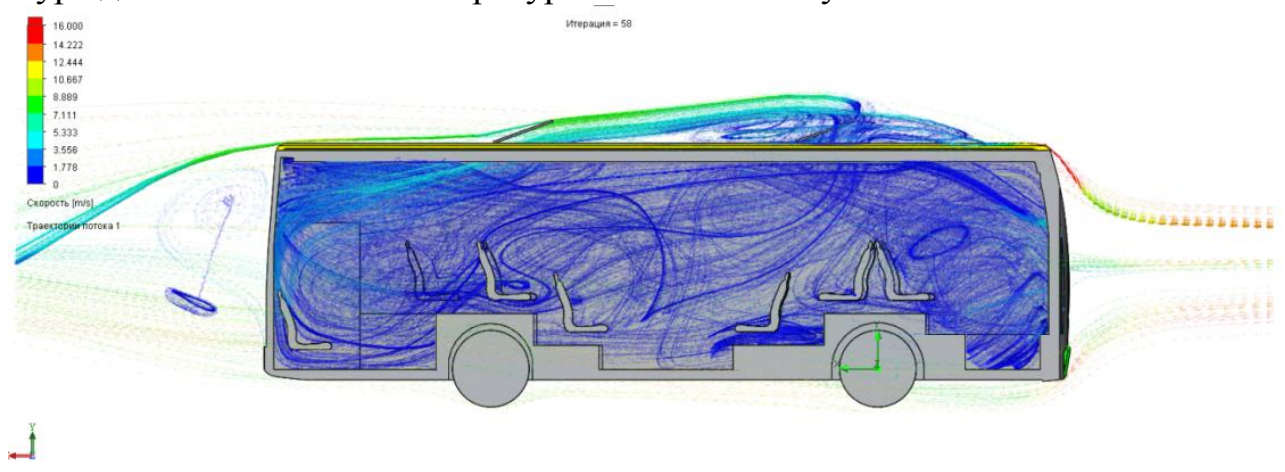

Рисунок 1 - Структура потоку вентильованого повітря при швидкості руху 65 км/год

В напрямку вдосконалення системи обігріву досліджувався вплив джерел обігріву на температурні поля і їх відповідність заданим нормам. В досліджуваному автобусі джерела обігріву знаходяться в передній і центральній частині салону. Температура повітря, що подається через трубопроводи може змінюватися в досить широких межах. При дослідженнях температрура приймалася $20^{\circ} \mathrm{C}$. Теплові потоки від обігрівачів піднімаються у верхню частину салону і рухаються до задньої частини салону (рис. 2). Оскільки обігрівачі знаходяться в правій частині салону, можна побачити, що в лівій частині, біля дверей спостерігаються зони холодної турбулентності 3 температурою $4 \ldots 6^{\circ} \mathrm{C}$.
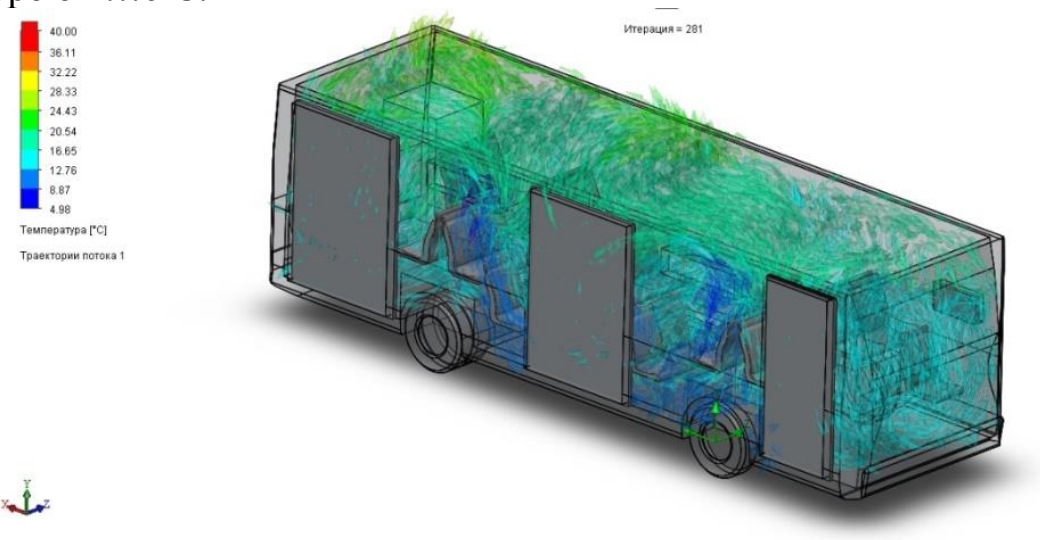

Рисунок 2 - Зони холодної турбулентності біля дверей

\section{ОБГОВОРЕННЯ РЕЗУЛЬТАТІВ ДОСЛІДЖЕННЯ}

Оскільки, сьогодні при конструюванні транспортного засобу одним із важливих питань є забезпечення комфортних умов для пасажирів і водія, у світі $\epsilon$ низка вчених, які займаються дослідженням систем забезпечення мікроклімату. Проаналізувавши вище наведені наукові роботи та дослідження та порівнявши їх із описаними у цій статті авторами подібними дослідженнями займалися у роботах [4], [12], [23]. Узагальнюючою тематикою усіх цих робіт є моделювання повітряних потоків у салоні транспортного засобу за допомогою комп'ютерних технологій та отримання у результаті так званих температурних полів у салоні транспортного засобу.

Моделювання повітряних потоків в салоні легкового автомобіля наведено в дослідженні [12]. Було досліджено ефективність обігріву вітрового і бокових вікон, ефективність вентиляції салону та ефективність опалення салону. Для дослідження було побудовано розрахункову модель повітряного простору салону створену по геометричним параметрам салону автомобіля. Результати показали, що найбільш ефективним місцем для виходу повітря із салону є зона під заднім вікном.

Моделювання повітряних та теплових потоків наведено у роботах [4] та [23]. За допомогою 
комп'ютерних технологій в обох роботах було створено симуляційну модель у середовищі ANSYS. За допомогою практичних досліджень [4] було встановлено температурне поле в салоні електробуса та температурні показники і різних ділянках салону автобуса. Як показали дослідження [23] найбільш сприятливим місцем виходу повітря в салоні автобуса $є$ вентиляційни отвір на задній стінці. Найменша рухливість повітря $є$ в передній частині салону.

\section{ВИСНОВКИ}

Для комфортних умов пасажирських перевезень необхідно вдосконалювати системи вентиляції і обігріву транспортних засобів. При цьому важливим $\epsilon$ визначення основних напрямків дослідження, які б базувалися на нових технологіях проектування вказаних систем з використанням САПР, а натурні випробовування мали б завершальний характер і були б малозатратними.

В системах вентиляції актуальними є дослідження складових системи (вентилятори, елементи повітропроводів, розміщення вхідних отворів і їх вплив на ефективність системи вентиляції в цілому.

В системах обігріву актуальними є дослідження параметрів і характеристик теплових потоків при різних режимах роботи агрегатів цих систем.

\section{ПЕРЕЛІК ДЖЕРЕЛ ПОСИЛАННЯ}

1. Любомир Крайник, Юрій Гай. Мікроклімат салону автобуса. Формування нормативної бази. Автобусобудування та пасажирські перевезення в Україні: тези доповідей III-ої Всеукраїнської науково-практичної конференції, Львів, 22-23 лютого 2018 року. Львів: Видавництво Львівської політехніки, 2018. С. 14-15.

2. ГОСТ Р 50993-96. Автотранспортные средства. Системы отопления, вентиляции и кондиционирования. Требования к эффективности и безопасности. Москва: ИПК издательство стандартов, 1997. $11 \mathrm{c.}$

3. Вильковский Е.К., Гнипович В.И. Характеристика климатических условий работы городских автобусов. Труды ВКЭИавтобуспрома. 1979. С. 142-149.

4. Прохоров И.В., Бутарович Д.О., Рябов Д.М. Исследование температурного поля воздуха обитаемых зон салона электробуса. Труды НГТУ им. Р.Е. Алексеева. 2019. №2 (125). С. 205 - 209.

5. Гнипович В.И., Жуковский С.С., Иванусь Е.М., Парфенов В.Н. Уменьшение загрязнения воздушной среды салона автобуса. Труды ВКЭИавтобуспрома. 1980. С. 159-166.

6. Худяков К. В. Обеспечение комфортных условий работы водителя на основе совершенствования характеристик вихревых труб и систем кондиционирования: автореф. дис. На соискание учёной степени канд. техн. наук: 05.22.10. Волгоград, 2007. 18 с.

7. Şaban Ünal. (2017). An Experimental Study on a Bus Air Conditioner to Determine its Conformity to Design and Comfort Conditions. Yildiz Technical University Press, pp.1089-1101.

8. Mehmet Bilgili, Ediz Cardak, Arif Emre Aktas. (2017). Thermodynamic Analysis of Bus Air Conditioner Working with Refrigerant R600a. European Mechanical Science, 1(2), pp.69-75.

9. Анализ теплового режима кабины транспортного средства: Монография / Устинов А.С., Савин И.К. - Издательство ПетрГУ. Петрозаводск, 2015. 91 с.

10. Матвеев Д. В. Разработка технологии расчета системы отопления и вентиляции легкового автомобиля: дис. канд. техн. наук: 05.05.03 / Ижевск. 2006. 123 с.

11. Елагин М.Ю. Математическая модель тепловлажностного расчёта системы «Кондиционер кабина» транспортного средства. Известия ТулГУ. Технические науки. 2015. Ч1. С. 81 - 90.

12. Барикин А.Ю., Басиров Р.Р., Мухаметдинов М.М. Оценка эффективности работы систем обеспечения микроклимата салона легкового автомобиля. Научно - технический вестник Поволжья. 2015. №2. С. 73-76.

13. Грицук И.В., Гущин А.М, Краснокутская 3.И., Момот М.С, Ушаков А.Л. Анализ требований к микроклимату рабочего места водителя колесного транспортного средства. Вісник Донецької академії автомобільного транспорту. 2014. №4. С. 66-71.

14. Лук'яненко В.М, Галич І.В. Аналіз вимог до мікроклімату на робочому місці оператора мобільної сільськогосподарської техніки. Вісник Харківського начіонального технічного університету сільського господарства ім. П. Василенка. 2010. Т. 2, Вип. 93. С. 232-247.

15. Соловьев М. А., Полуянович Н. К. Исследование распределения и динамики внутренних процессов функционирования системы кондиционирования воздуха. Молодой ученый. 2012. №11. С. $88-92$.

16. Chien-Lun Weng and Lih-Jen Kau. (2019). Design and implementation of a Low - Energy Consumption Air - Conditioning system of smart vehicle. Hindawi Journal of Healthcare Engineering. 
Article ID 3858560, 14.

17. S.S.Mathapati, Mudit Gupta, Sagar Dalimkar. (2014). A Study on Automobile Air-Conditioning Based on Absorption Refrigeration System Using Exhaust Heat of a Vehicle. International Journal Of Engineering Research and General Science, 2(4) July.

18. Nishant Agarwal1, Ekhlak Khan. (2018). Automobile Air Conditioning System. International Research Journal of Engeneering and Technology (IRJET), 05 Issue 06 June, pp.2121 - 2125.

19. S Rați, I Laza, V Alexa and V G Cioată. (2018). Practical studies on car air conditioning systems. IOP Conf. Series: Materials Science and Engineering, 393, p.6.

20. Terry J. Hendricks. (2001). Optimization of vehicle air conditioning systems using transient air conditioning performance analysis. National Renewable Energy Laboratory. Copyright 2001 Society of Autmotive Engeneers, p.10.

21. Бутенко А.Г. Влияние поперечного градиента вязкости на характеристики ламинарного потока в трубе кольцевого сечения. Труды ОПУ: научный и научно-производственный сборник по техническим и естественным наукам. 2005. Вып. 1(23). - С. 185-188.

22. А. Гупта. Д. Лилли, Н. Сайред. Закрученные потоки / пер.с англ: Мир. Москва, 1987. 588 с.

23. Т.І. Круць, Р.В. Зінько, Д.Г. Музичка, Ю.М. Черевко. Дослідження швидкісних і температурних показників в процесі вентиляції салону автобуса. «Прогресивна техніка, технологія та інженерна освіта» (IIPTK-2019): матеріали тез доповідей XX міжнародної науково-технічної конференції (м. Київ-Херсон, 10-13 вересня 2019 р.) / КПІ ім. І.Сікорського [та ін.]. 2019. - С.174-179.

\section{REFERENCES}

1. Lyubomyr Kraynyk, Yuriy Hai. (2018). Mikroklimat salonu avtobusa. Formuvannya normatyvnoyi bazy. Avtobusobuduvannya ta pasazhyrski perevezennya v Ukrayini: tezy dopovidey III-yi Vseukrayinskoyi naukovo-praktychnoyi konferentsiyi, Lviv, 22-23 lyutoho 2018 roku, 14-15.

2. GOST R 50993-96. (1997). Avtotransportnyye sredstva. Sistemy otopleniya, ventilyztsii i konditsionirovaniya. Trebovaniya k effektivnosti i bezopasnosti, 11.

3. Vilkovskiy, E.K., Hnipovich, V.I. (1979). Harakteristika klimaticheskih usloviy raboty horodskih avtobusov. Issledovaniye $i$ raschyot konstruktsyy $i$ expluatatsionnoy nadyozhnosti avtobusov. Trudy VKEIavtobusproma, 142-149.

4. Prohorov, I.V., Butarovich, D.O., Ryabov, D.M. (2019). Issledovaniye temperaturnoho polya vozduha obitayemyh zon salona elektrobusa. Mashynostroyeniye $i$ transport: teoriya, tehnolohii, proizvodstvo. Trudy NHTU im. R.E. Alexeeva, 2 (125). 205 - 209.

5. Hnopovich, V.I., Zhukovskiy, S.S., Ivanus, E.M., Parfyonov, V.N. (1980). Umensheniye zahryaznyeniya vozdushnoy sredy salona avtobusa. Issledovaniye $i$ raschyot konstruktsiy $i$ expluatatsionnoy nadyozhnosti avtobusov. Trudy VKEIavtobusproma, 159-166.

6. Hudyakov, K.V. (2007). Obespecheniye komfortnyh usloviy raboty vodityelya na osnovye sovershenstvovaniya harakteristik vyhrevyh trub i sistem konditsionirovaniya: avtoref. dis. na soiskaniye uchonoy stepeni kand. tehn. nauk: 05.22.10, 18.

7. Şaban Ünal. (2017). An Experimental Study on a Bus Air Conditioner to Determine its Conformity to Design and Comfort Conditions. Yildiz Technical University Press, 1089-1101.

8. Mehmet Bilgili, Ediz Cardak, Arif Emre Aktas. (2017). Thermodynamic Analysis of Bus Air Conditioner Working with Refrigerant R600a. European Mechanical Science, 1(2), 69-75.

9. Analiz teplovoho rezhyma kabiny transportnoho sredstva: Monohrafiya / Ustinov, A.S., Savin, I.K. (2015) - Izdatelstvo PetrHU. Petrozavodsk, 91.

10. Matveyev, D.V. (2006) Razrabotka tehnolohii raschyota sistemy otopleniya i ventilyatsii lehkovogo avtomobilya: dis. kand. tehn. nauk: 05.05.03, 123.

11. Elahin, M.Y. (2015) Matematicheskaya model teplovlazhnostnoho raschyota sistemy «Konditsioner - kabina» transportnoho sredstva. Izvestiya TulHU. Tehnicheskiye nauki, 1, $81-90$.

12. Barikin, A.Y., Basirov, R.R., Muhametdinov, M.M. (2015). Otsenka effektivnosti raboty sistem obespecheniya mikroklimata salona lehkovoho avtomobilya. Nauchno - tehnicheskiy vestnik Povolzhya, 2, 73-76.

13. Hrizuk, I.V., Hushchin, A.M., Krasnokutskaya, Z.I., Momot, M.S, Ushakov, A.L. (2014). Analiz trebovaniy $\mathrm{k}$ mikroklimatu rabocheho mesta voditelya kolyosnoho transportnoho sredstva. Visnyk Donetskoyi akademiyi avtomobilnoho transport, 4, 66-71.

14. Lukyanenko, V.M., Halych, I.V. (2010). Analiz vymoh do mikroklimatu na robochomu mistsi operatora mobilnoyi silskohospodarskoyi tehniky. Visnyk Harkivskoho natsionalnoho tehnichnoho 
universytetu silskoho hospodarstva imeni Petra Vasylenka, 93, T. 2, 232-247.

15. Solovyov, M. A., Poluyanovich, N. K. (2012). Issledovaniye raspredeleniya i dinamiki vnutrennih protsessov funktsionirovaniya sistemy konditsionirovaniya vozduha. Molodoy uchonyy, 11, 88-92.

16. Chien-Lun Weng and Lih-Jen Kau. (2019). Design and implementation of a Low - Energy Consumption Air - Conditioning system of smart vehicle. Hindawi Journal of Healthcare Engineering. Article ID 3858560, 14.

17. Mathapati, S.S., Mudit Gupta, Sagar Dalimkar. (2014). A Study on Automobile Air-Conditioning Based on Absorption Refrigeration System Using Exhaust Heat of a Vehicle. International Journal Of Engineering Research and General Science, 2(4) July.

18. Nishant Agarwal1, Ekhlak Khan. (2018). Automobile Air Conditioning System. International Research Journal of Engeneering and Technology (IRJET), 05 Issue 06 June, 2121 - 2125.

19. Rați, S., Laza, I., Alexa, V. and Cioată, V.G. (2018). Practical studies on car air conditioning systems. IOP Conf. Series: Materials Science and Engineering, 393, 6.

20. Terry J. Hendricks. (2001). Optimization of vehicle air conditioning systems using transient air conditioning performance analysis. National Renewable Energy Laboratory. Copyright 2001 Society of Autmotive Engeneers, 10.

21. Butenko, A.G. (2005). Vliyaniya poperechnogo gragiyenta vyazkosti na harakteristiki laminarnoho potoka v trube koltsevoho secheniya. Trudy Odesskoho politehnicheskoho universiteta: nauchnyy i nauchnoproizvodstvennyy sbornik po tehnicheskim i yestestvyennym naukam, 1(23), 185-188.

22. Gupta, A., Lilli, D., Sayred, N. (1987). Zakruchyonnyye potoki / per.s angl., Mir. 588.

23. Kruts, T.I., Zinko, R.V., Muzychka, D.H., Cherevko, Y.M. (2019). Doslidzhennya shvydkisnyh i temperaturnyh pokaznykiv v protsesi ventylyatsiyi salonu avtobusa. "Prohresyvna tehnika, tehnolohiya ta inzhenerna osvita» (PRTK-2019): materialy tez dopovidey XX mizhnarodnoyi naukovo-tehnichnoyi konferentsiyi (m. Kyiv-Kherson, 10-13 veresnya 2019 r.), 174-179.

\section{Y. Voichyshyn, T. Kruts, R. Zinko, O. Horbai. Study of the microclimate of large vehicles.}

The analysis of existing scientific researches of domestic and foreign scientists in the field of research of microclimate of vehicles is carried out in the work. The state of research is analyzed and what issues of this direction of scientific research need to be investigated.

The structure and main functions performed by microclimate systems in the cabins of buses, cars and agricultural tractors are considered. One of the factors that determine the well-being of passengers is the microclimate in the interior of the vehicle. The parameters that characterize it include temperature, humidity, air mobility and the presence of harmful substances. The methods of calculation and design of heating and ventilation systems used today are based on integrated methods that allow to determine only the average flow parameters.

The main role in the design of such systems is given to experimental research, road and climate testing, which is costly. Therefore, it is important to determine the basic parameters of the microclimate at the stage of design or improvement of the sample and they would be based on new technologies for designing these systems using computer-aided design systems, and field tests would be final and low cost. In the course of research of the offered subjects the simulation 3D - model of air streams in salon of the largesized bus was created. With the help of created 3D - models you can visually see the movement of air flows in the cabin of the bus when it moves or when stopped. Modern computer technology allows you to assess the state of the thermal state inside the vehicle in the warm or cold season. Therefore, studies of this kind can serve as a further basis for a broader study, analysis of problems and the provision of recommendations for addressing microclimate problems.

Key words: microclimate of the passenger compartment, heating system, interior ventilation, interior air conditioning, air flows, turbulence zone, turbulent flows, heating source, temperature fields.

ВОЙЧИШИН Юрій Іванович, студент першого курсу магістратури, кафедри автомобілебудування, Національний університет «Львівська політехніка» e-mail: Jurko-Q@ukr.net.

КРУЦЬ Тарас Ігорович, асистент кафедри автомобілебудування, Національний університет «Львівська політехніка» e-mail: 21-ladk@ukr.net

ЗІНЬКО Роман Володимирович, кандидат технічних наук, доцент кафедри автомобілебудування, Національний університет «Львівська політехніка» e-mail: rzinko@ gmail.com

ГОРБАЙ Орест Зенонович, доктор технічних наук, завідувач кафедри автомобілебудування, Національний університет «Львівська політехніка»е-mail: orest_60@yahoo.ca 
Yurii VOICHYSHYN, student, Department of Automotive Engineering, Lviv Polytechnic National University e-mail: Jurko-Q@ukr.net.

Taras KRUTS, assistant of the automotive engeneering department, Lviv Polytechnic National University e-mail: 21-ladk@ukr.net

Roman ZINKO, PhD in engeneering, Department of Automotive Engineering, Lviv Polytechnic National University e-mail: rzinko@gmail.com

Orest HORBAI, Doctor of Technical Sciences, Head of the Department of Automotive Engineering, Lviv Polytechnic National University e-mail: orest_60@yahoo.ca.

DOI 10.36910/automash.v1i14.346 